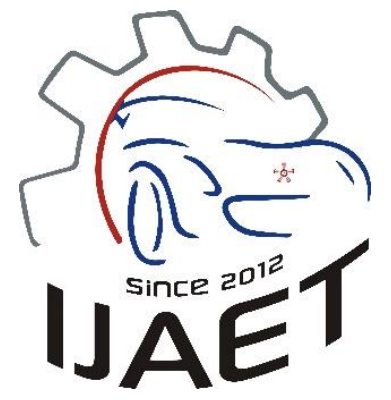

e-ISSN: 2146 - 9067

International Journal of Automotive

Engineering and Technologies

journal homepage:

https://dergipark.org.tr/en/pub/ijaet

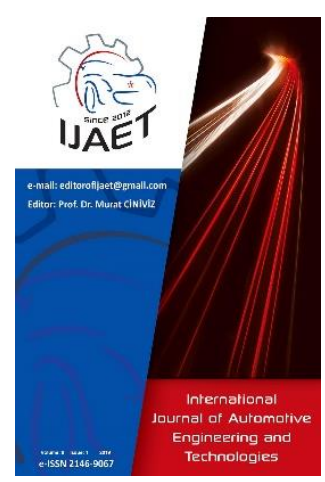

Original Research Article

\title{
An Experimental Investigation on The Effects of Waste Olive Oil Biodiesel on Combustion, Engine Performance and Exhaust Emissions
}

\author{
Fatih Aksoy ${ }^{1}$, Fatih $\mathrm{Akay}^{2}$, Şükrü Ayhan Baydır ${ }^{1}$, Hamit Solmaz $^{3}$, Emre Y1lmaz \\ Ahmet Uyumaz ${ }^{*}$, Bilal Aydoğan ${ }^{6}$, Alper Calam ${ }^{7}$

\begin{abstract}
${ }^{1}$ Afyon Kocatepe University, Faculty of Technology, Department of Automotive Engineering, Afyon, Turkey ${ }^{2}$ Nedime Serap Ulusoy Vocational and Technical High School, Samsun, Turkey

3Gazi University, Faculty of Technology, Department of Automotive Engineering, Ankara, Turkey

${ }^{4}$ Hakkâri University, Faculty of Engineering, Mechanical Engineering Department, Hakkâri, Turkey

${ }^{6}$ Burdur Mehmet Akif Ersoy University, High Vocational School of Technical Sciences, Burdur, Turkey ${ }^{7}$ Gazi University, Ostim High Vocational School, Ankara, Turkey
\end{abstract} \\ ${ }^{5}$ Burdur Mehmet Akif Ersoy University, Faculty of Engineering, Mechanical Engineering Department, Burdur, Turkey
}

\section{ARTICLE INFO}

* Corresponding author auyumaz@mehmetakif.edu.tr

Received: June 14, 2019

Accepted: Sep 11, 2019

Published by Editorial Board Members of IJAET

(C) This article is distributed by Turk Journal Park System under the CC 4.0 terms and conditions.

\begin{abstract}
In this study, the biodiesel obtained from the waste olive oil by transesterification method has been mixed with a $30 \%$ of diesel fuel as volume and tested with a single cylinder direct injection diesel engine. The main purpose of this study is to obtain purer biodiesel from waste olive oil using methyl alcohol $\left(\mathrm{CH}_{3} \mathrm{OH}\right)$ and sodium hydroxide $(\mathrm{NaOH})$ as catalyst in the transesterification method and research performance, combustion and emission characteristics in detail in a direct injection diesel engine. The combustion, engine performance and exhaust emission values have been also compared with diesel fuel. The test engine was operated at a constant speed of $2200 \mathrm{rpm}$ and different engine loads such as $3.25 \mathrm{Nm}, 7.5 \mathrm{Nm}, 11.25 \mathrm{Nm}$, $18.75 \mathrm{Nm}$. According to the experimental results, the thermal efficiency of biodiesel is lower by about $1 \%$ to $5 \%$ than diesel. $\mathrm{CO}$ is lower about $37.5 \%$ with biodiesel than that of diesel at $18.75 \mathrm{Nm} . \mathrm{CO}_{2}$ is higher $41 \%$ with biodiesel than diesel at $11.25 \mathrm{Nm}$. $\mathrm{NO}_{x}$ was measured $9.5 \%$ higher than diesel fuel at $18.75 \mathrm{Nm}$. Soot emissions decreased by $37.5 \%$ compared to diesel.

Keywords: Biodiesel, Exhaust Emissions, Transesterification, Engine Performance, Combustion
\end{abstract}

\section{Introduction}

Nowadays, energy needs of countries are increasing rapidly due to industrialization and technological development. Due to the energy crisis, countries have begun to focus on developing alternative energy sources to meet their energy needs. Therefore, the development of renewable energy sources with low emissions that can be used in diesel engines is very important for both environment and human health [1]. One of the alternative fuels that can be used in compression-ignition engines is biodiesel obtained from vegetable or animal fats [2]. Direct usage of vegetable oils in diesel engines leads to problems such as insufficient atomization due to high viscosity, high levels of smoke emission, incomplete combustion, carbon deposits, ring adhesion and 
obstruction of the injectors. Despite the high flash point of vegetable oils, low volatility is another important disadvantage [3]. The density and viscosity of biodiesel fuels is higher than that of diesel and cold working properties are not better than standard diesel fuel. At this point, it can cause fuel injection system problems. It is possible to use biodiesel fuels in internal combustion engines by reducing disadvantaged aspects. Therefore, methods such as microemulsions, pyrolysis and transesterification have been performed to use vegetable oils as alternative fuels in diesel engines. Among these methods, transesterification have been widely used [4]. Transesterification reaction is alkaline catalyzed, acid catalyzed and enzyme catalyzed [4-7]. Dorado et al [8] investigated the chemical parameters of waste olive oil biodiesel. The results showed that using $\mathrm{KOH}$ and methanol gave better results than using $\mathrm{NaOH}$ and ethanol. Abed et al [9] researched the effects of cooking-oil biodiesel on engine performance and exhaust emissions of a Kirloskar make, single cylinder, four strokes, and direct injection diesel engine with a developing power of $5.775 \mathrm{~kW}$ at $1500 \mathrm{rpm}$. They have found that thermal efficiency of waste cooking-oil biodiesel were lower than that of diesel fuel and specific fuel consumptions were higher. Gao et al. [10] investigated the effects of waste cooking oil biodiesel on kinetics, fuel properties and engine performance and emissions. They reported that engine torque of biodiesel is lower than diesel fuel. Shen et al [11] evaluated the effects of waste cooking oil biodiesel blends on the exhaust emissions and fuel consumption of two light-duty diesel truck and two heavy-duty diesel trucks. The results showed that the fuel consumption and $\mathrm{CO}_{2}$ emissions of biodiesel blends were higher than that of neat diesel fuel due to the lower calorific value of biodiesel blends. Yesilyurt [12] presented the effects of the fuel injection pressure on the performance and emission characteristics of a diesel engine fueled with waste cooking oil biodiesel-diesel blends. The experiments showed that engine torque, brake power, $\mathrm{CO}$, UHC and smoke opacity decreased and BSFC, exhaust gas temperature, $\mathrm{NO}_{\mathrm{x}}$ and $\mathrm{CO}_{2}$ emissions increased for the biodiesel fuel blends. Akar et al [13] evaluated the effects of waste oil biodiesel on the engine performance and exhaust emission characteristics of a compression ignition engine. They have seen that using biodiesel deteriorated performance and emission parameters except CO. Rajak and Verma [14] presented the effects of edible and non-edible vegetable oil, animal fats, waste oil and alcohol in CI engine. The results showed that the PM emissions and smoke emissions reduced and $\mathrm{NO}_{\mathrm{x}}$ pollutant increased with the usage of biodiesel. Gharehghani et al [15] evaluated the effects of waste fish oil biodiesel on diesel engine combustion characteristics and emissions at a single cylinder E6 Ricardo engine. They reported that in-cylinder pressure increased, heat release rate duration shortened with fish oil biodiesel. Garcia-Martin et al [16] produced waste cooking oil biodiesel in an oscillatory flow reactor (OFR) and tested engine performance of a TDI diesel engine. The results showed that biodiesel yield in OFR was higher than in stirred tank reactor. The particle number concentration decreased for especially B50 fuel (38\%). Dorado et al [17] investigated the effects of waste olive oil methyl ester in a Diesel direct injection Perkins engine at several steady-state operating conditions. They have found that $\mathrm{CO}, \mathrm{CO}_{2}, \mathrm{NO}$ and $\mathrm{SO}_{2}$ decreased and $\mathrm{NO}_{2}$ increased with the usage of olive oil biodiesel methyl ester when compared to the conventional diesel fuel. Lapuerta et al [18] evaluated the effects of the alcohol type used in the production of waste cooking oil biodiesel and tested the fuels in a 2.21 , common rail injection diesel engine. The results showed that fuel consumption slightly increased and sharp reduction in total hydrocarbon emissions, smoke opacity and particle emissions when compared to diesel engine. Lapuerta et al [19] investigated the effects of cooking oil biodiesel on particulate emissions of DI diesel commercial engine at a typical road conditions. Smoke and particulate matter emissions were sharply decreased as the biodiesel concentration was increased. Kalligeros et al [20] tested different biodiesel (rape seed oil, sunflower oil, olive oil)/marine diesel blends in single cylinder, indirect injection diesel engine and detected fuel consumption and exhaust emissions. The reduction of $\mathrm{HCs}$ and $\mathrm{CO}$ emissions were 
explained with the faster evaporation and more stable combustion. Dorado et al [21] evaluated waste olive oil methyl ester as a fuel for diesel engines during 50-h short term performance test in a disel direct injection Perkins engine. They have seen that slight power loss and brake-specific fuel consumption increase. Energy conversion efficiency remained constant or showed slight increase for waste olive oil methyl ester when compared to No.2 Diesel fuel. David et al. [22] investigated the mutagenicity emission factors of canola oil and waste vegetable oil biodiesel. it was seen that utagenic potencies of canola and waste vegetable oil emissions are higher than $\mathrm{B} 0$. Nawel et al. [23] aimed to reduce energy and reactant consymptions to obtain green process. They showed that maximum oil conversion of $100 \%, 2.69 \mathrm{~kJ}$ minimum energy consumption and $77.36 \%$ maximum green chemistry balance with $\mathrm{KOH}$ catalyst concentration of $2 \mathrm{wt} \%$. Carmano-cabello et al. [24] intended to optimize biodiesel production with lipid fraction included in solid food waste. They analyzed biodiesel quality with cold properties (below- $3{ }^{\circ} \mathrm{C}$ ). Conversion efficiency should be enough high in transesterification method in view of purer and reasonable biodiesel production. So, production process and catalysts are evident in order to obtain good biodiesel. This phonomena directly affects the combustion phasing and performance. So, there is knowledge gap in this field. In the current study, biodiesel was obtained from waste olive oil by transesterification method using methyl alcohol $\left(\mathrm{CH}_{3} \mathrm{OH}\right)$ and sodium hydroxide $(\mathrm{NaOH})$ as catalysts. High level of biodiesel addition to pure diesel deteriorated the properties of test fuel, injection and combustion characteristics due to lower calorific value and higher viscosity and density. Hence, the produced biodiesel was mixed with $30 \%$ by volume of diesel fuel. So, B30 fuel was experimentally tested in a single-cylinder, natural-aspirated, direct-injection diesel engine and its effects on combustion, engine performance and exhaust emissions.

\section{Experimental Setup and Procedures}

The engine test and emission measurements of the biodiesel produced by the transesterification method from waste olive oil were carried out.

\subsection{Biodiesel production}

In the current study, biodiesel production was carried out by transesterification method from waste olive oil. Methyl alcohol $\left(\mathrm{CH}_{3} \mathrm{OH}\right)$ and sodium hydroxide $(\mathrm{NaOH})$ as catalyst were used during production. In the biodiesel purification process, water washing method was applied. Diesel fuel is mixed with $30 \%$ olive oil methyl ester and tested in a single cylinder, direct injection engine and its effects on engine performance and exhaust emission were investigated. Glass balloon, cooler, flat glass balloon, separating hopper, kinematic viscometer, density measuring device, cetane number and cetane index measuring device, water determination measuring device, sulfur amount measuring device, magnetic stirrer, magnetic fish, precision balance were used in biodiesel production. The mixture and heating process are carried out by adding the crude oil into the methoxide after the methanol and the catalyst are completely mixed and the methoxide is formed. Raw oil and methoxide on magnetic cooker is allowed to be mixed by rotating magnetic fish by means of magnetic heater at $40 \mathrm{rpm}$ for 1 hour at $60^{\circ} \mathrm{C}$ temperature. Temperature makes easier to occur transesterification reaction. During these heating operations, the temperature control is kept under observation with a thermometer for a certain period of time and the magnetic heater is reached to the required temperature. The aim of this process is to prevent the methanol from starting to boil about $63-67{ }^{\circ} \mathrm{C}$. Refrigerant pipe (cooler) circulates water. In this way, it prevents the evaporation of the evaporating alcohol due to the increase of heat by condensing with the help of cold water. The mixture was allowed to rest for an average of 12 hours at the end of the mixing process. The biodiesel and glycerin decomposed at the end of this waiting period. Glycerin was withdrawn from the biodiesel by separating funnel due to the difference of the density of glycerin and biodiesel. The produced biodiesel must be washed to remove unreacted alcohols, fatty acids and catalyst material. Otherwise, these substances in the fuel may cause abrasive effect on rubber or rubber connected engine parts. Biodiesel, separated from glycerin, is subjected 
to biodiesel washing process to separate the fatty acids and catalyst residues of alcohols remaining in biodiesel by keeping for half an hour in $100{ }^{\circ} \mathrm{C}$ boiled water in separating funnel.

As shown in Figure 1, the washing process was repeated using the bubble method by adding boiled water in the biodiesel.
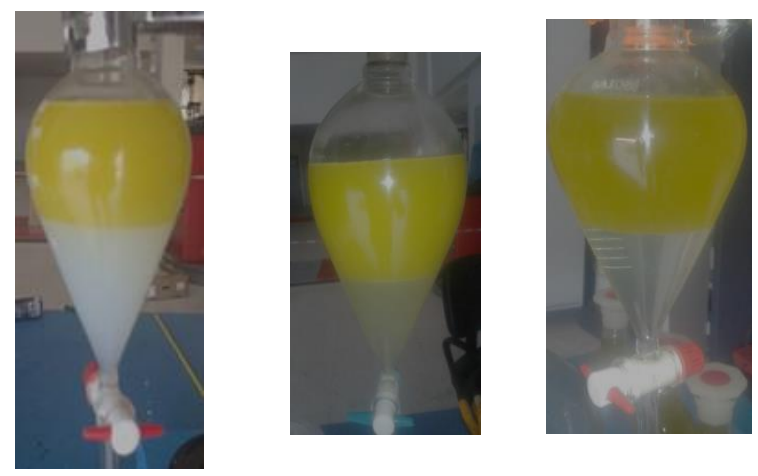

a) First washing

b) Second washing

c) Third washing

Figure 1. The washing process of biodiesel

This process continues until the color of the water becomes clear. Thus, the purest biodiesel is obtained. After separating biodiesel from water, biodiesel is applied to drying process to remove water completely from the biodiesel. Drying process continues at evaporation temperature of water above $100{ }^{\circ} \mathrm{C}$ in the 110 $120{ }^{\circ} \mathrm{C}$ temperature range until evaporation ends. It was put into the beaker on the heated magnetic stirrer and it was heated by stirring with the magnetic fish.

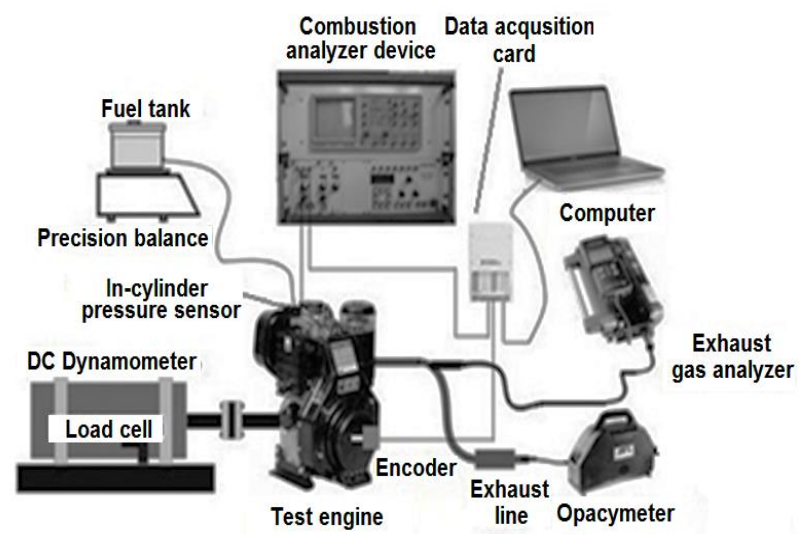

Figure 2. Schematic view of the experimental setup

\subsection{Engine tests and emissions measurement}

The effects of waste olive oil biodiesel on combustion, performance and exhaust emissions have been investigated experimentally. For this purpose, the test engine was operated at $2200 \mathrm{rpm}$ and at different loads $(3.75,7.5,11.25,15$ and 18.75
$\mathrm{Nm})$. The schematic view of the experimental setup is shown in Figure 2. The experiments were carried out at Gazi University, Faculty of Technology, Automotive Engineering Department Internal Combustion Engines Laboratory.

The experiments were conducted in a single cylinder, direct injection, naturally aspirated diesel engine. The technical specifications of the test engine are given in Table 1.

Table 1. The technical specifications of the test engine

\begin{tabular}{ll}
\multicolumn{2}{c}{$[25]$} \\
\hline Model & Antor / 6LD400 \\
\hline Engine Type & Direct injection, naturally \\
Cylinder number & 1 \\
Bore x Stroke $[\mathrm{mm}]$ & $86 \times 68$ \\
Swept volume $\left[\mathrm{cm}^{3}\right]$ & 395 \\
Compression ratio & $18: 1$ \\
Maximum power $[\mathrm{kW}]$ & $5.4 @ 3000 \mathrm{rpm}$ \\
Maximum torque $[\mathrm{Nm}]$ & $19.6 @ 2200 \mathrm{rpm}$ \\
Combustion chamber geometry & $\omega$ type \\
Fuel injection system & PF Jerk type fuel pump \\
Injection nozzle & 0.24 [mm] x 4 hole x $160^{\circ}$ \\
Injection timing $\left[{ }^{\circ} \mathrm{CA}\right]$ & 24 BTDC \\
\hline
\end{tabular}

The experiments were carried out at constant intake air inlet $\left(25^{\circ} \mathrm{C}\right)$ and engine oil temperatures $\left(80{ }^{\circ} \mathrm{C} \pm 1\right)$. The tests and measurements were performed after the engine was reached to operating temperature. The test engine was coupled with Cussons P8160 test bed and loaded with a DC dynamometer as shown in Figure 3. The dynamometer can able to absorb $10 \mathrm{~kW}$ of power at $4000 \mathrm{rpm}$. Engine load can be determined by strain gauge load cell. Magnetic pick-up sensor was used to measure engine speed. Engine oil and intake air inlet temperatures were measured with K-type thermocouples and temperatures were kept constant during the experiments. AVL 8QP500c quartz model water cooled pressure sensor was used for measuring cylinder pressure. After the cylinder pressure data is taken from the pressure sensor, the data was amplified with Cussons P4110 combustion analyzer and the analog data was transferred to the data acquisition card.

Diesel and B30 (30\% biodiesel-70\% diesel) test fuels were used in the experiments. The properties of test fuels are shown in Table 2.

Analog cylinder pressure data has been converted to digital data using National Instruments USB 6259 brand data acquisition card. Digital pressure data was then recorded 
on the computer. The encoder was mounted on the crankshaft, which produces 360 pulses per revolution. It was also used to determine the engine speed and the top dead center (TDC).

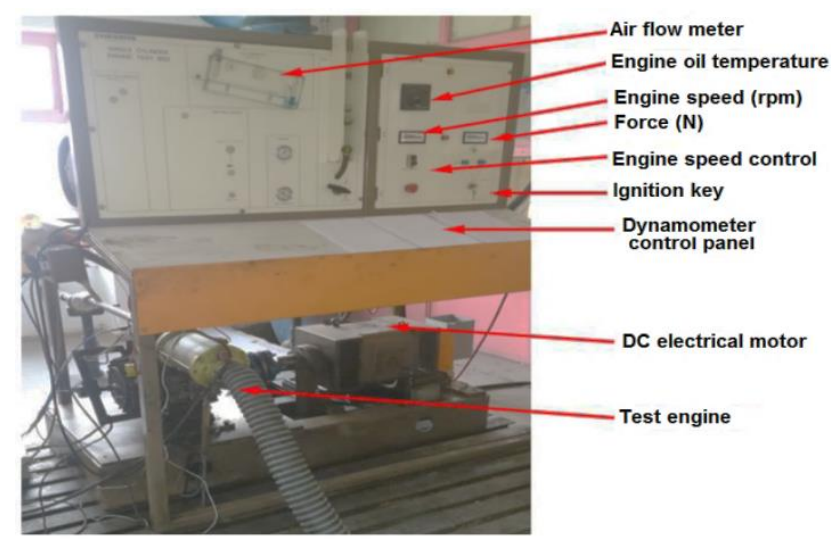

Figure 3. Test setup

Table 2. The properties of test fuels

\begin{tabular}{lll}
\hline Properties & Diesel & Biodiesel \\
\hline Calorific value $[\mathrm{kJ} / \mathrm{kg}]$ & 45343 & 39488 \\
Density $\left[\mathrm{kg} / \mathrm{m}^{3} @ 15^{\circ} \mathrm{C}\right]$ & 842 & 921 \\
Kinematic viscosity $\left[\mathrm{cst} @ 40^{\circ} \mathrm{C}\right]$ & 2.44 & $3.6-4.42$ \\
Freezing point $\left[{ }^{\circ} \mathrm{C}\right]$ & $<-5$ & 6 \\
Cetane number & $>50$ & 57 \\
\hline
\end{tabular}

Crank angle information was measured at intervals of $0.36^{\circ} \mathrm{CA}$. The cylinder pressure of consecutive 50 cycles were averaged to reduce cyclic differences. For combustion analysis, combustion characteristics such as heat release, start of combustion and combustion duration were determined by using cylinder pressure data. Exhaust emissions in the tests were measured with the Testo exhaust gas analyzer with the technical specifications given in Table 3.

Table 3. Technical specifications of Testo Exhaust gas analyzer

\begin{tabular}{|c|c|c|}
\hline $\begin{array}{l}\text { Combustion } \\
\text { products }\end{array}$ & $\begin{array}{l}\text { Operating } \\
\text { range }\end{array}$ & Accuracy \\
\hline $\mathrm{O}_{2}$ [vol.\%] & $0-25$ & $\pm 2 \mathrm{mV}$ \\
\hline $\mathrm{CO}[\mathrm{ppm}]$ & $0-10000$ & 5 ppm (0-99 ppm) \\
\hline $\mathrm{CO}_{2}$ [vol.\%] & $0-50$ & $\begin{array}{l} \pm 0,3 \text { vol. } \%+1 \mathrm{mV} . \%(0-25) \\
\text { vol. } \% \text { ) }\end{array}$ \\
\hline $\mathrm{HC}[\%]$ & $0.01-4$ & $<400$ ppm $(100-4000$ ppm $)$ \\
\hline $\mathrm{NO}_{\mathrm{x}}[\mathrm{ppm}]$ & $0-3000$ & 5 ppm (0-99 ppm) \\
\hline
\end{tabular}

Table 4. Technical specifications of AVL Di-Smoke 4000

\begin{tabular}{ccc}
\hline Analyzer & AVL DiSmoke 4000 \\
\hline Measurement method & \multicolumn{2}{c}{ Partial flow } \\
& Opacity & K value \\
Operating range & $0-100 \%$ & $0.1 \%$ \\
Accuracy $\left[\mathrm{m}^{-1}\right]$ & $0-99.99$ & 0.01 \\
\hline
\end{tabular}

Soot emissions in the tests were measured with the AVL Di-Smoke 4000 opacimeter given the technical specifications in Table 4.

In the experiments, the variables such as thermal efficiency and combustion characteristics were determined at constant engine speed. Heat release rate was determined using cylinder pressure depending on the first law of thermodynamics. When calculating the heat release, it is assumed that the in-cylinder charge mixture is the ideal gas. It is thought that there are no gas leakages. Equation (1) was used to calculate the heat release rate.

$\frac{d Q}{d \theta}=\frac{k}{k-1} P \frac{d V}{d \theta}+\frac{1}{k-1} V \frac{d P}{d \theta}+\frac{d Q_{\text {heat }}}{d \theta}$

In Equation (1), dQ represents heat release, $\mathrm{dQ}$ heat heat transferred to cylinder walls, $\mathrm{d} \theta$ crank angle, and $\mathrm{k}$ ratio of specific heat. Cylinder pressure and fuel line pressure must be determined for combustion analysis. Figure 4-a shows the change in fuel line pressure due to the crank angle. The first derivative of cylinder pressure, heat release and cylinder pressure is shown in Figure 4-b.
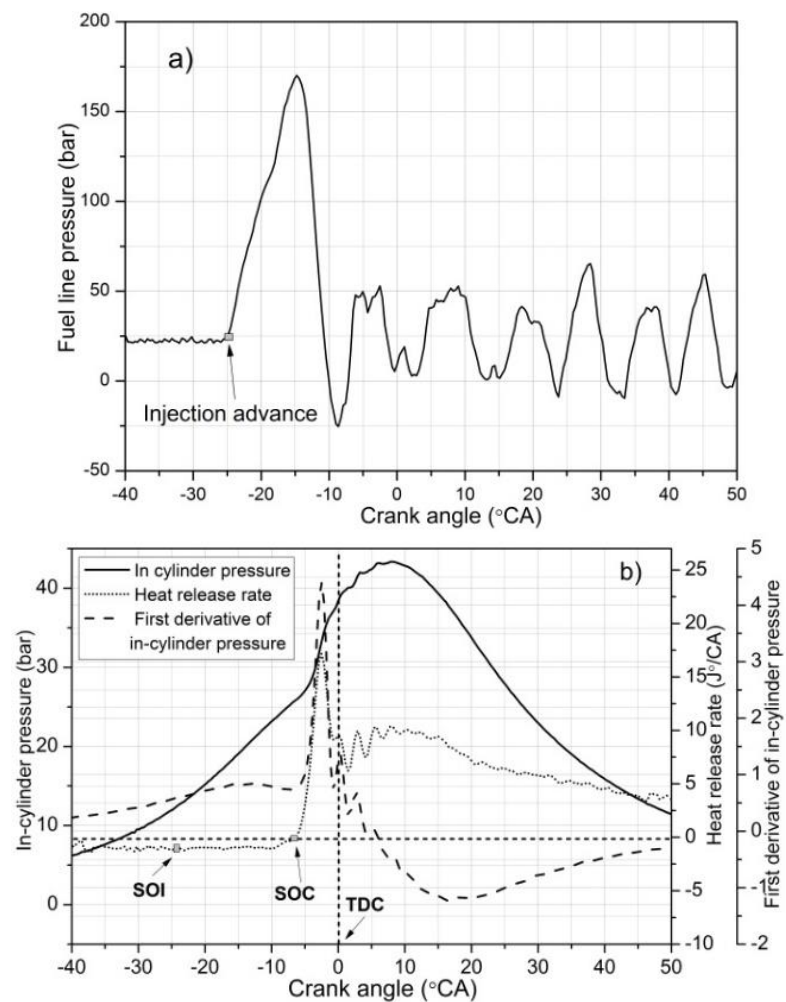

Figure 4. a) Fuel line pressure b) The first derivative of cylinder pressure, heat release and cylinder pressure

In the experiments, the start of combustion was accepted as the point where the heat release increased from negative value to positive value according to the crank angle. The time between the start of the injection and the start of the 
combustion indicates the ignition delay. The original start of injection timing of the test engine is $24{ }^{\circ} \mathrm{CA}$ BTDC. It is difficult to determine when the combustion ends. However, the end of combustion is defined as the point at which $90 \%$ of the mixture is completed. The heat from the cylinder to the walls depends on the thermodynamic conditions in the combustion chamber [26-28].

\section{Results and Discussions}

\subsection{Cylinder pressure change}

As engine load increased, in-cylinder pressures increased. The maximum in-cylinder pressure was obtained ATDC at high engine load. When B30 was used at $18.75 \mathrm{Nm}$ load, it was seen that the in-cylinder pressure is higher than diesel (about 44 bar). When comparing with diesel, B30 presented higher in-cylinder pressure with the increase of engine load. It can be implied that high density of biodiesel caused to increase in-cylinder pressure due to higher density during injection. The variations of incylinder pressure are shown in Figure 5. Besides, higher oxygen content of biodiesel improves oxidation reactions in the combustion chamber. Hence, fuel can be well combusted in the presence of sufficient oxygen. At higher engine loads, more time is required in order to complete combustion. So, combustion is retarded. This phonomena is especially noticed with B30 due to higher viscosity and density of waste oil biodiesel. Uyumaz et al. [29] showed that the addition of sunflower oil biodiesel caused to increase in-cylinder pressure. Uyumaz [30] noticed that in-cylinder pressure increased with the increase of mustard oil biodiesel addition into pure diesel. He found that the highest in-cylinder pressure was measured with M30 at $15 \mathrm{Nm}$ engine load.

Uyaroğlu et al. [31] mentioned that no big differences were seen on cylinder pressure between hazelnut oil-diesel (H30), corn oildiesel (C30), soybean oil-diesel (S30), sunflower oil-diesel (Su30), canola oil-diesel (Ca30) and Crambe abyssinica oil-diesel (Cr30) and diesel fuel blends. They have also stated that eralier combustion occured with biodiesel-diesel fuel blends. Uyumaz [30] noticed that there was no big difference between diesel and mustard oil biodiesel-diesel blends on heat release rate. Can et al [32] showed that the addition of soybean biodiesel into diesel resulted in higher in-cylinder pressure ad heat release with EGR. On the other hand, there are studies in the literature that biodiesel addition showed lower incylinder pressure and heat release [33-36].
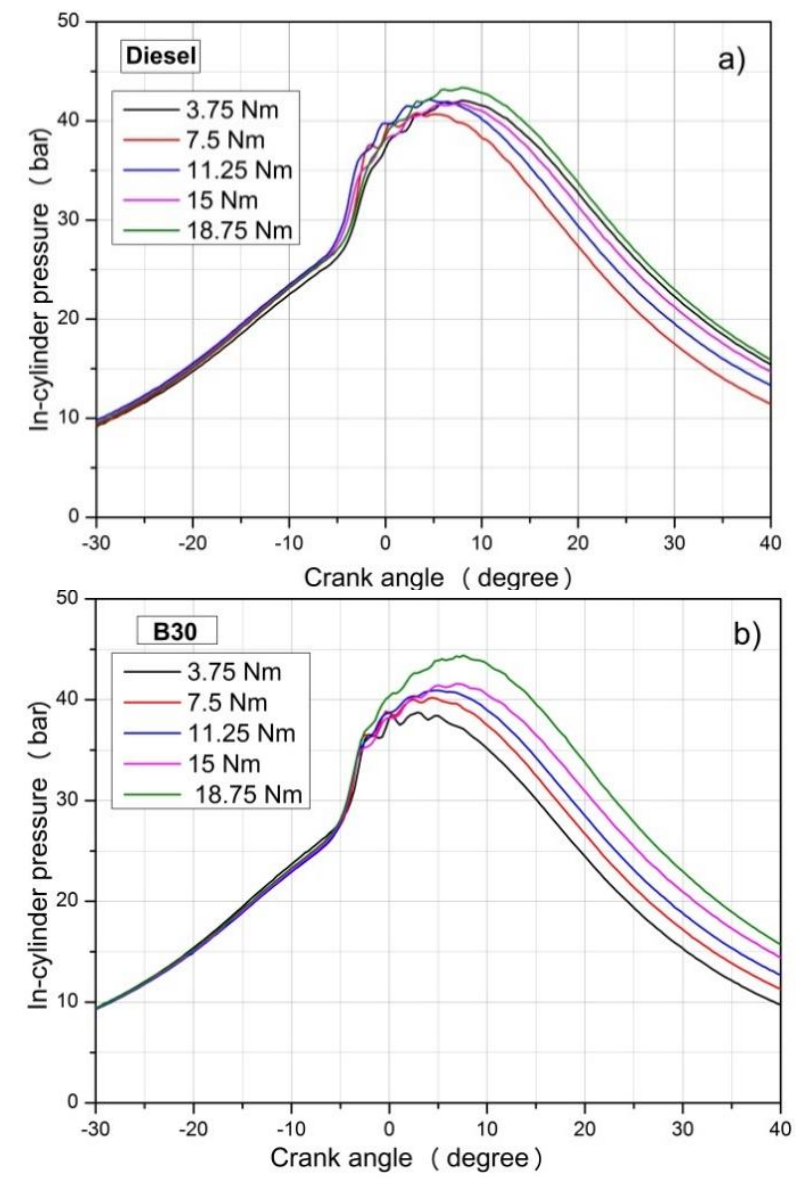

Figure 5. a) The variations of in-cylinder pressure of diesel fuel b) The variations of in-cylinder pressure of B30 fuel

The longer the ignition delay, the more fuel is injected into the cylinder before combustion. This causes fuel accumulation in the cylinder and the sudden combustion of excess fuel molecules increase the maximum in-cylinder pressure [37]. At lower loads, lower fuel is sent to the cylinder and the maximum in-cylinder pressure is getting lower. As the amount of fuel injected increases with the increase of engine load, in-cylinder gas pressure increases. As the engine load increases, the maximum cylinder gas pressure moves away from the TDC [38].

\subsection{The heat release rate change versus crank angle}

When heat release rate is examined, the maximum heat release rate was obtained as 23 $\mathrm{J} /{ }^{\circ} \mathrm{CA}$ at $7.5 \mathrm{Nm}$ engine load at $3{ }^{\circ} \mathrm{CA}$ BTDC 
with diesel fuel. In the case of $\mathrm{B} 30$ fuel, the heat release rate is approximately $22 \mathrm{~J} /{ }^{\circ} \mathrm{CA}$ at the same engine load at the same crank angle.

The variations of heat release rate are shown in Figure 6. Heat release was observed to reach the maximum level at $7.5 \mathrm{Nm}$ engine load for both test fuels.
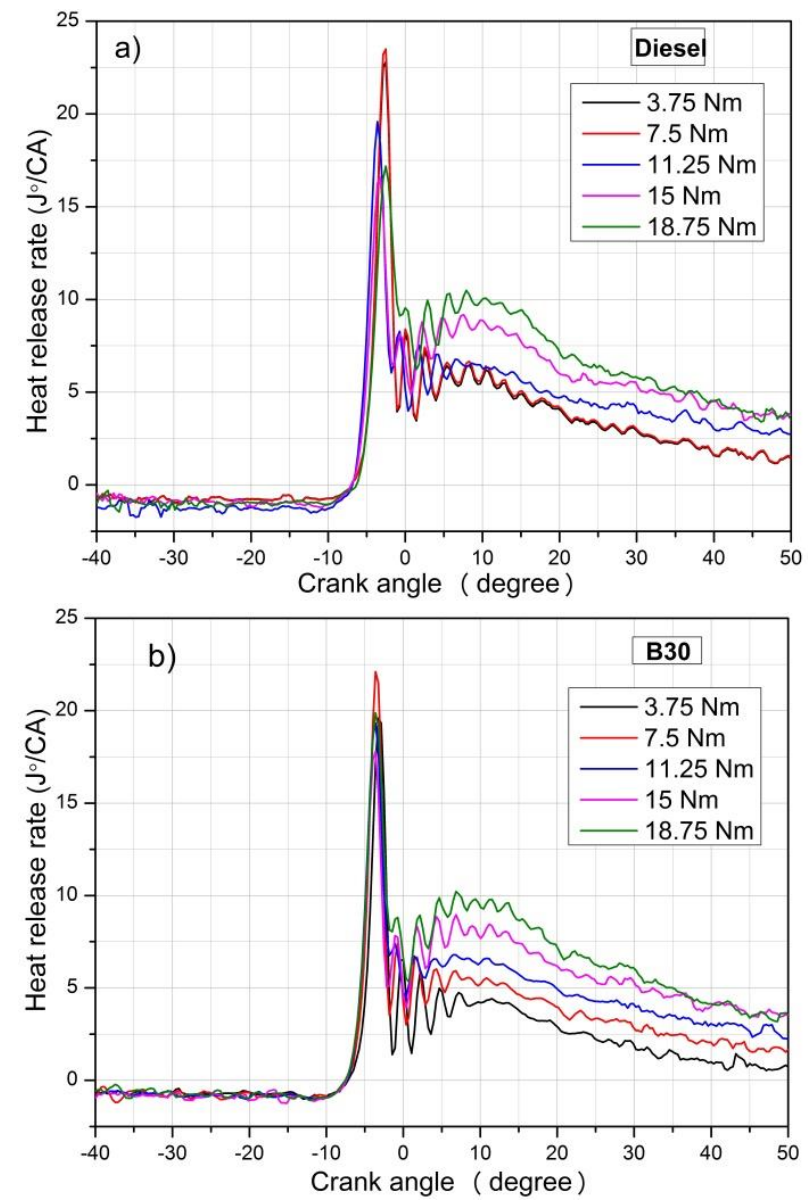

Figure 6. a) The variations of heat release rate with diesel b) The variations of heat release rate with B30

The heat release rate is similar in the same engine torque and crank angle for both fuel. In terms of the crank angle, sudden combustion period was completed at the same position versus crank angle for both fuels. Çelik et al. [39] presented that maximum heat release rate was obtained at nearly the same crank angle position with the addition of $\mathrm{n}$-heptan into diesel.

\subsection{Ignition delay change versus engine load}

As the engine load increases, the ignition delay is shortened. Minimum ignition delay was obtained about $0.73 \mathrm{~ms}$ and $0.86 \mathrm{~ms}$ for diesel and B30 respectively at full load. The ignition delay of B30 fuel is longer. Combustion of more fuel molecules lead to increase incylinder temperature and combustion improves.
Thus, fuel evaporates earlier and the ignition delay decreases. Figure 7 shows ignition delay change versus engine load. Lower calorific value, high viscosity and density of biodiesel increased the ignition delay [40]. Çelik et al. [40] found that the shortest ignition delay was obtained with PH8. Uyaroğlu et al. [31] found the shortest ignition delay period with hazelnut oil biodiesel-diesel fuel blends at full load. In another study, Çelik et al. [41] investigated the effects of organic based manganese addition into diesel. They showed that the highest ignition delay was obtained with pure diesel. Besides ignition delay period shortened with the addition of manganese.

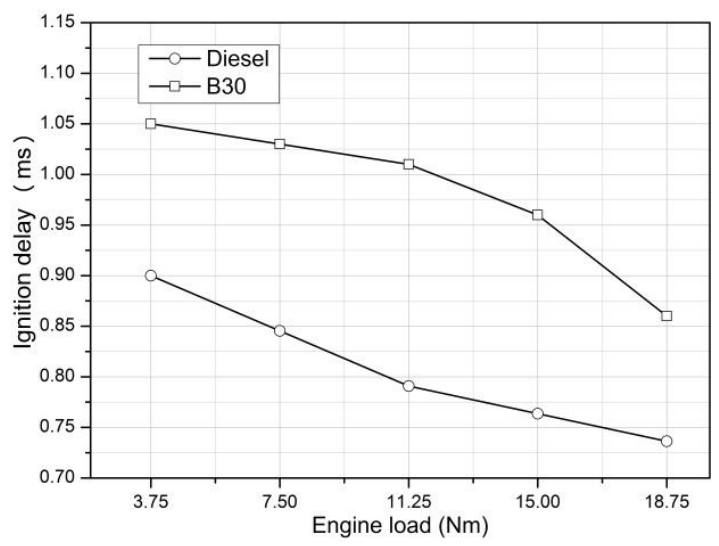

Figure 7. Ignition delay

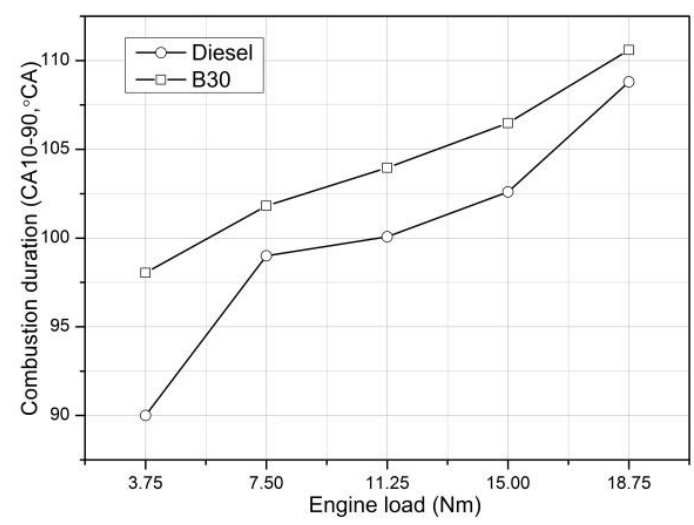

Figure 8 . The variations of combustion duration

\subsection{Combustion duration versus engine load}

With the increase of the engine load for both fuels, the combustion duration increases. At 18.75 $\mathrm{Nm}$ engine load, combustion duration was determined about $108{ }^{\circ} \mathrm{CA}$ and $111^{\circ} \mathrm{CA}$ with diesel and $\mathrm{B} 30$ respectively. At low engine speeds, the difference in combustion duration is high between the two fuels. When the engine load increases, the difference between the combustion duration of both fuels begins to decrease. The high density and 
viscosity of the B30 increases the combustion duration. The combustion duration is desired to be completed at the time of diffusion combustion period and at earlier crank angle. At the same engine torque value, the combustion duration of the B30 fuel is higher than that of diesel fuel. The change in combustion duration is shown in Figure 8 . Higher density and viscosity of biodiesel prolonged the combustion duration, because physical delay period increased before the combustion. More time and sufficient temperature is needed in the combustion chamber in order to start combustion with biodiesel-diesel blends.

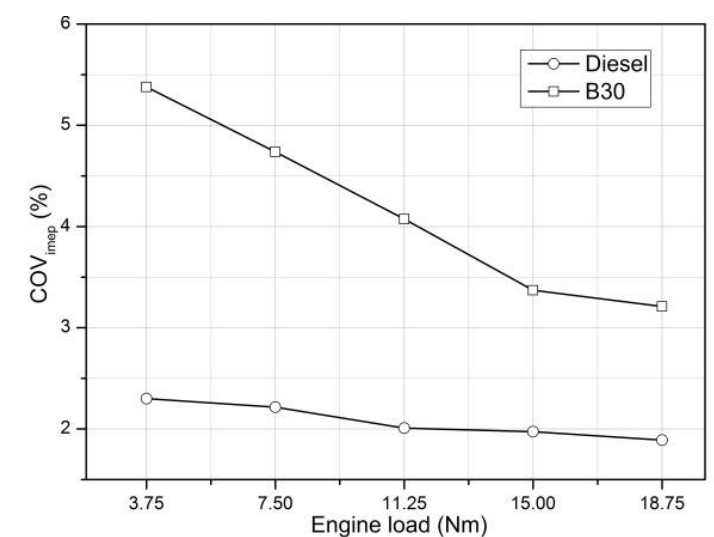

Figure 9. The cyclic variations depending on the engine load

\subsection{Cyclic variations}

It is observed that the cyclic variations are higher with biodiesel at the same engine load. However, as the engine load increases, the difference between the two fuels decreases. Variation of the mixture composition, the temperature and pressure differences in the cylinder cause cyclic variations. In the literature, the coefficient of cyclic variations (COV) should not exceed $10 \%$ for stable engine operation. Whole residual exhaust gas could not be discharged from the combustion chamber and they remain in the combustion chamber for the next cycle. So, In-cylinder charge composition varies at the end of compression stroke. This phonomena causes incomplete combustion and it results in cyclic variations. Figure 9 shows the cyclic variations depending on engine load. It can be said that more stable combustion was seen with diesel compared that B30. B30 showed resistance for physical and chemical decomposition before the combustion. This phonomena resulted in higher ignition delay period and combustion duration. Prolonged ignition delay caused to sudden combustion with B30 compared to diesel. So, unregulated combustion is seen with B30.

\subsection{Variation of maximum pressure rise rate versus engine load}

The difference between the pressure rise rates is higher at low engine loads. This difference decreases with the increase of engine load. It is seen that the pressure rise rates are close each other at $11.25 \mathrm{Nm}$ engine load. Crank angle where the maximum in-cylinder pressure was obtained and pressure rise rate can be computed while 50 consecutive cycles are averaged versus crank angle. Knocking limit can be defined by pressure rise rate in the internal combustion engines for stable operation. Knocking is seen when the maximum pressure rise rate exceeds 10 bar $/{ }^{\circ} \mathrm{CA}$ in the internal combustion engines. The first derivative of in-cylinder pressure gives the pressure rise rate. The pressure rise rate is determined by taking numerical derivative according to the first degree of the cylinder pressure values versus crank angle. If the maximum pressure rise rate did not exceed $10 \mathrm{bar} /{ }^{\circ} \mathrm{CA}$, no knocking was observed. Figure 10 shows the maximum pressure rise rates versus engine load.

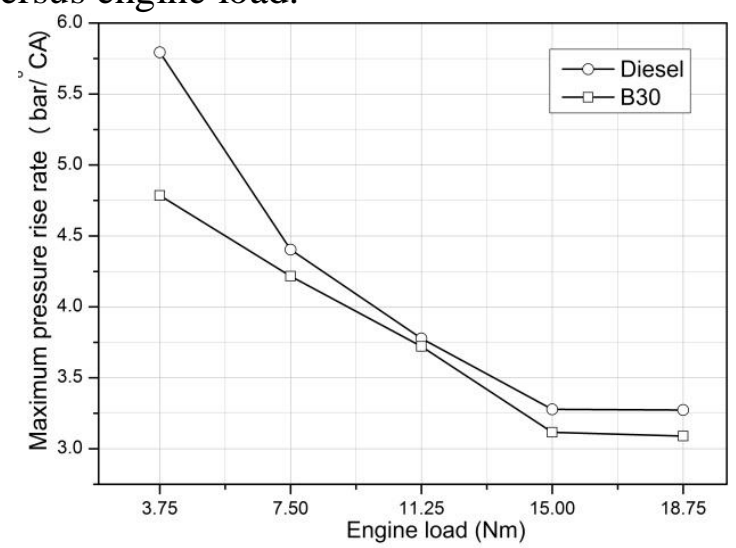

Figure 10. The change of maximum pressure rise rate

\subsection{Cumulative heat release}

The cumulative heat release is used to calculate the amount of mass burned versus the crank angle. Mass burned fraction can be determined by normalizing the heat release between 0 1300 J. The cumulative heat release obtained during the combustion period as a result of combustion gives us information about the 
percentage of burning fuel when normalized treatment between 0-1300 J. The crank angle, where the cumulative heat release reaches $10 \%$ $(130 \mathrm{~J})$, is considered to be the crank angle where $10 \%$ of the in-cylinder fuel amount is completed. The cumulative heat release reaches $90 \%$ (1170 J), which corresponds to the crank angle at which $90 \%$ of the fuel amount completes the combustion. Usually the time taken for combustion is defined as the time between $10 \%$ and $90 \%$ of the burning fuel in terms of the crank angle. As the crank angle increases, the cumulative heat release is increased parabolically. The cumulative heat release at the same engine speed and the same engine load at the same crank angle in the use of the B30 fuel shows a similar trend to diesel fuel. Figure 11 shows the cumulative heat release.

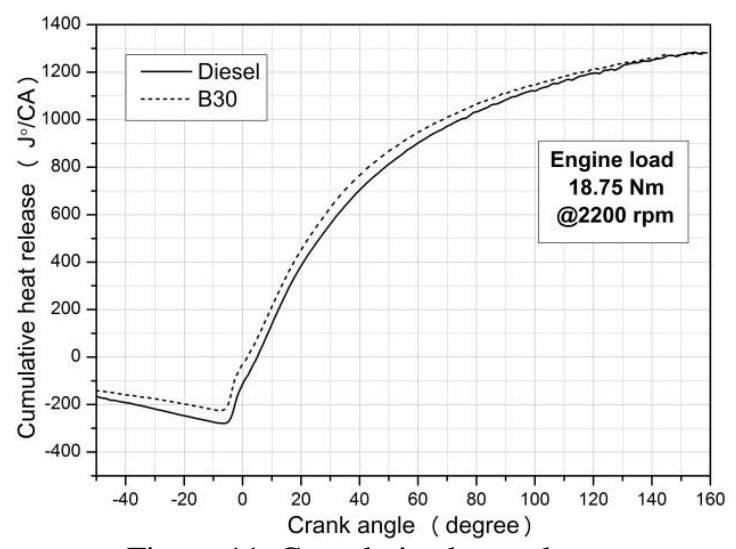

Figure 11. Cumulative heat release

\subsection{The variation of CA50 versus engine load}

CA50 is the crank angle where corresponds to $50 \%$ of the cumulative heat release. If CA50 is obtained far away from TDC, İndicated thermal efficiency decreases. Figure 12 shows that CA50 of the B30 fuel is higher than that of diesel fuel at specified engine load. This shows that the point where half of the mixture burns is longer than the TDC. This effect causes to decrease of thermal efficiency of B30.

\subsection{The variation of indicated thermal efficiency versus engine load}

Indicated thermal efficiency of diesel is higher than B30 fuel. However, while the indicated thermal efficiency of diesel fuel is $28 \%$ at $11.25 \mathrm{Nm}$ engine load, the indicated thermal efficiency of B30 fuel is $26 \%$. At the same engine loads, indicated thermal efficiency is better $\max 5 \%$ and $\min 1 \%$ at diesel fuel. Figure 13 shows the variations of indicated thermal efficiency versus engine load. Due to the high viscosities of fuels, it has more latent heat for evaporation and the indicated thermal efficiency is low. High viscosity and density cause the formation of larger droplets during the spraying of the fuel and the insufficient mixture with the air by evaporating [42]. Can et al. [32] showed that B20 presented similar thermal efficiency with diesel without EGR. It can be emphasized that more fuel fraction is needed for the same power output. So, brake specific fuel consumption increases and thermal efficiency decreases with the usage of biodiesel $[11,12]$.

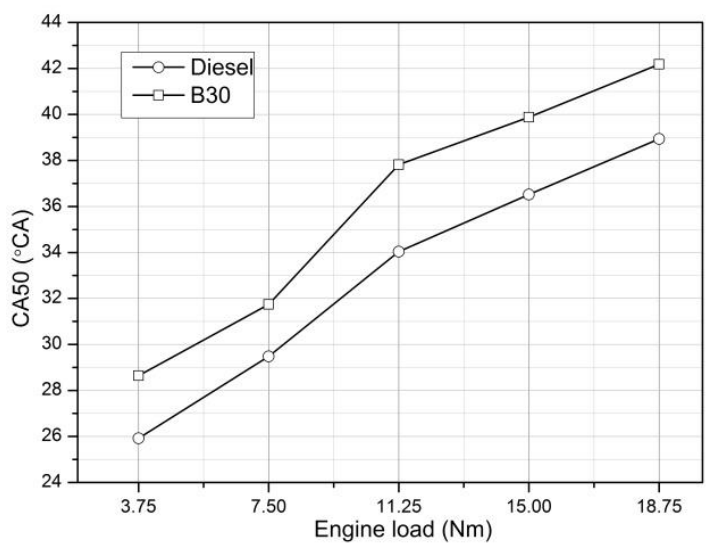

Figure 12. The variation of CA50

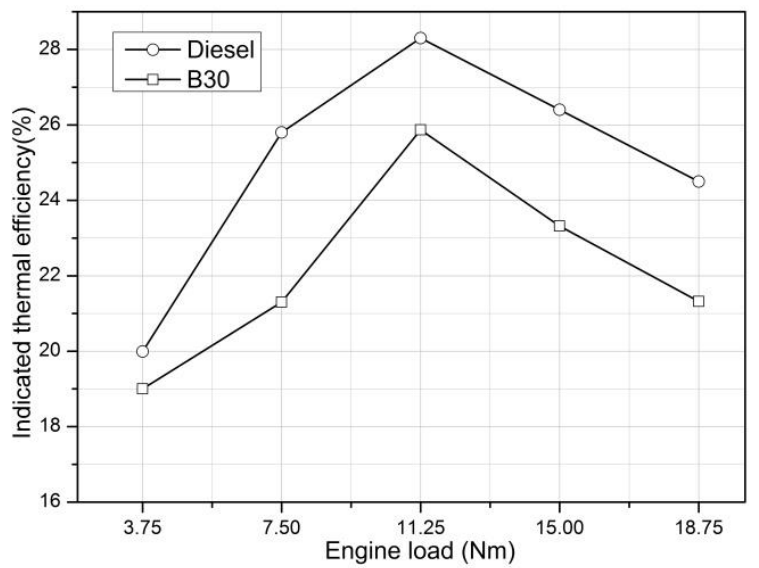

Figure 13. The variations of indicated thermal efficiency versus engine load

\subsection{The variations of co and $\mathrm{CO}_{2}$ versus engine load}

$\mathrm{CO}$ is an incomplete combustion product due to insufficient temperature and oxygen content. In both diesel and B30 fuel use, CO emission rate increases depending on the engine load. Since the oxygen concentration decreases in the combustion chamber as the load increases, 
the formation of $\mathrm{CO}$ increases. However, this increase rate is higher in diesel fuel. The CO ratio is higher in diesel fuel than in biodiesel at $18.75 \mathrm{Nm}, 3.75 \mathrm{Nm}$ engine loads about $31 \%$ and $12.5 \%$, respectively. The oxygen content in biodiesel mixtures reduces $\mathrm{CO}$ emissions by providing more efficient combustion in the region where combustion is rich [41,42]. $\mathrm{CO}_{2}$ emissions also increase due to engine load in both fuels, but this increase is higher in diesel fuel than in B30 fuel. The B30 fuel contains oxygen, which improves the combustion process and improves the combustion quality. The $\mathrm{CO}_{2}$ ratio of biodiesel is higher than the diesel about $41 \%$ and $20 \%$ for the engine loads of $11.25 \mathrm{Nm}$ and $3.75 \mathrm{Nm}$, respectively. The change in $\mathrm{CO}$ and $\mathrm{CO}_{2}$ due to the motor load is shown in Figure 14. If the air-to-fuel ratio is controlled $\mathrm{CO}$ emissions may be reduced but the amount of $\mathrm{CO}_{2}$ increases accordingly. The formation of $\mathrm{CO}_{2}$ by reacting $\mathrm{CO}$ and oxygen depends on the combustion chamber temperature. Therefore, $\mathrm{CO}$ decreases with speed and $\mathrm{CO}_{2}$ is increased [43]. Biodiesel has higher $\mathrm{CO}_{2}$ emissions than diesel fuel due to the higher fuel consumption [44].
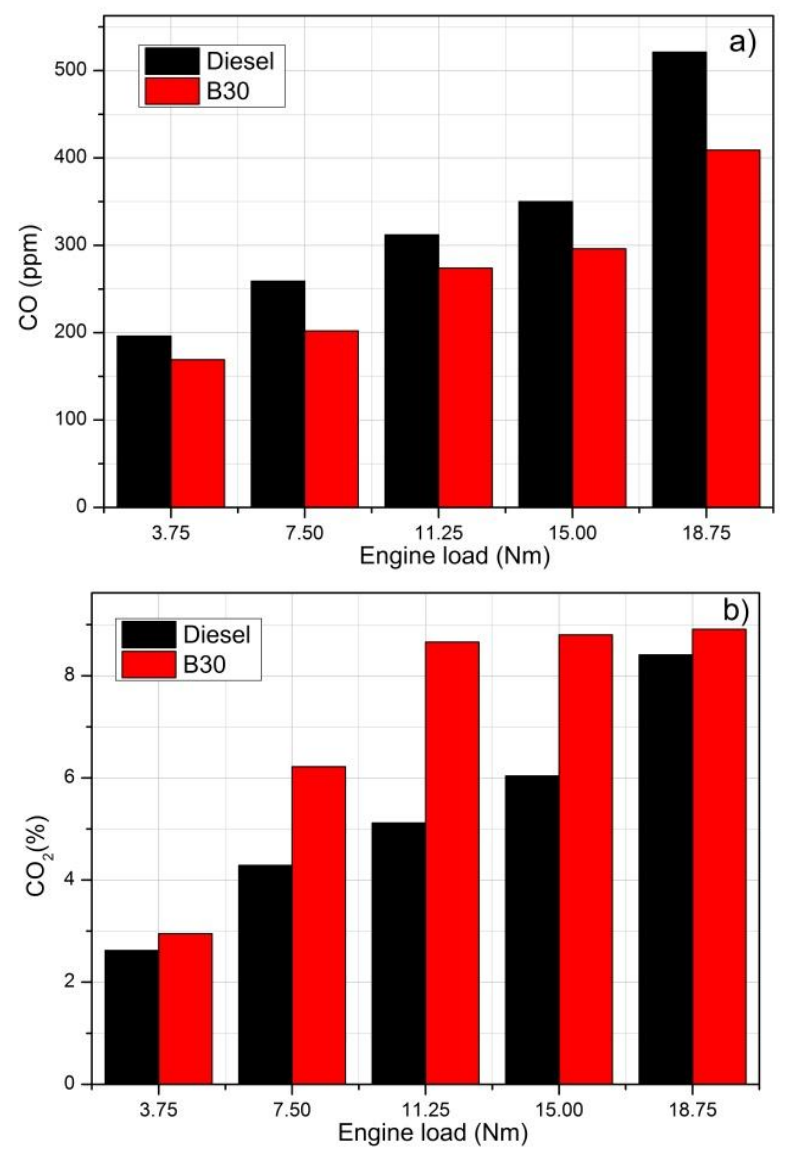

Figure 14. The variations of $\mathrm{CO}$ and $\mathrm{CO}_{2}$ versus engine load

\subsection{The variations of NOx versus engine load}

$\mathrm{NO}_{\mathrm{x}}$ emission for diesel and B30 fuel increase with the increase of engine load. However, $\mathrm{NO}_{\mathrm{x}}$ emission in the same engine load is higher than the $\mathrm{NO}_{\mathrm{x}}$ emission in diesel fuel when B30 fuel is used. The minimum $\mathrm{NO}_{\mathrm{x}}$ difference is $0.75 \%$ at $11.25 \mathrm{Nm}$ engine load and maximum $33 \%$ at $3.75 \mathrm{Nm}$. $\mathrm{NO}_{\mathrm{x}}$ increases due to high combustion end gas temperatures. It is thought that nitrogen and oxygen molecules react and $\mathrm{NO}_{\mathrm{x}}$ forms when the temperature is high during combustion. The engine load $\mathrm{NO}_{\mathrm{x}}$ change is shown in Figure 15.

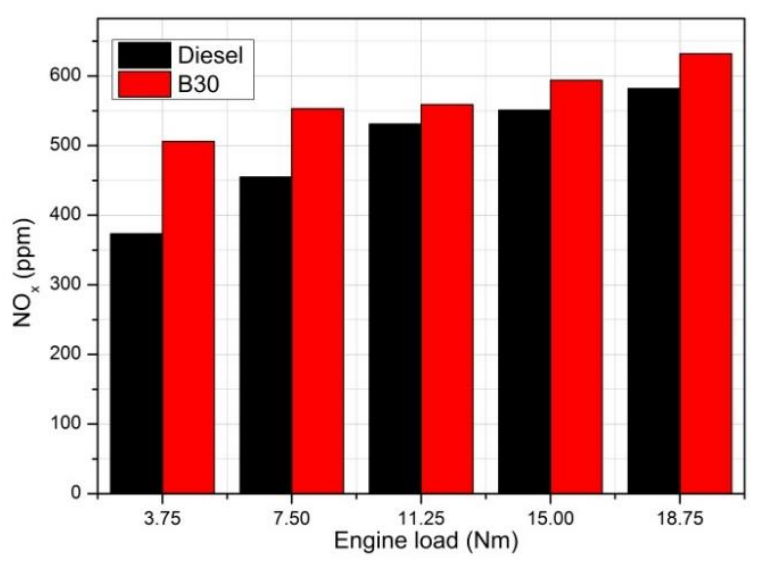

Figure 15. The variations of $\mathrm{NO}_{\mathrm{x}}$ versus engine load

Depending on the oxygen content of biodiesel fuels, $\mathrm{NO}_{\mathrm{x}}$ may show a tendency to increase according to diesel fuel values. Because oxygen increases the efficiency of the combustion and the combustion end gas temperature increases and can be effective in nitrogen gas to be converted into $\mathrm{NO}_{\mathrm{x}}$ emissions [45]. The presence of $11 \%$ oxygen in biodiesel fuel improves the combustion performance and increases the combustion end temperatures, thus increasing the $\mathrm{NO}_{\mathrm{x}}$ emission [45-46].

\subsection{The variation of soot emissions versus engine load}

Smoke emissions are increasing due to increase in engine load in both diesel and B30 fuels. Smoke emission rates for the same engine loads are higher in diesel fuel use. Oxygen content of waste olive biodiesel and low sulfur content cause smoke emissions to decrease. At full load, smoke emissions decreased by $37.5 \%$ in B30 fuel compared to diesel fuel. The change in smoke emissions is shown in Figure 16. 


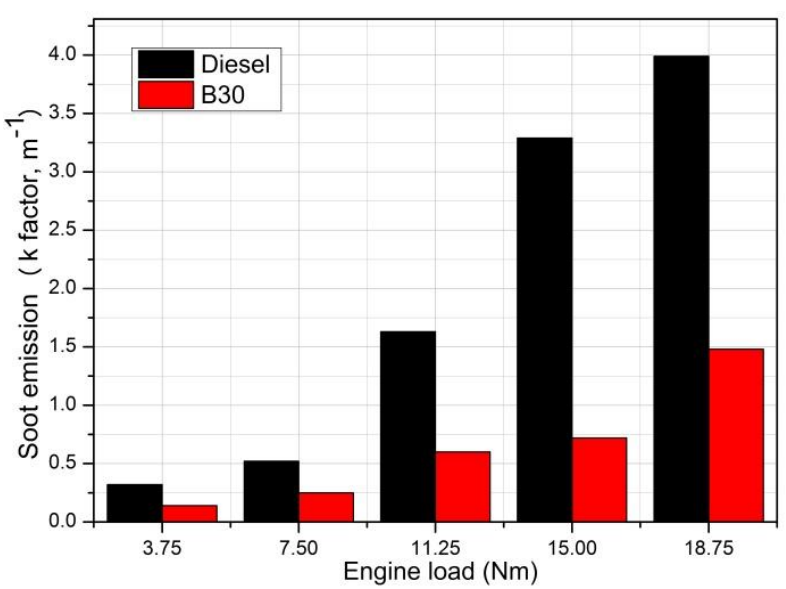

Figure 16. The variations of soot emissions versus engine load

The low sulfur content of the biodiesel, the presence of oxygen in the molecular content and the high air surplus coefficients increase the combustion efficiency, and the very small extent of $\mathrm{SO}_{3}$ release is effective in the reduction of smoke emissions [44-46]. The presence of oxygen in the biodiesel and the low sulfur rate are effective in reducing the emission of smoke.

\section{Conclusions}

Detailed analysis should be required using purer biodiesel in view of performance, combustion and emissions in diesel engines. The properties of obtained biodiesel improved the injection process and combustion behaviour. So, detail investigation was aimed using waste oil biodiesel in order to determine performance, combustion and emissions in the present study. In this study, biodiesel was produced from waste olive oil by one-step transesterification method and B30 fuel was obtained by mixing $30 \%$ by volume of diesel fuel. B30 fuel was tested in a single-cylinder direct-injection diesel engine and engine performance and exhaust emission values were determined. Then, diesel fuel was tested in the same engine and combustion, engine performance and exhaust emission values were determined and the results obtained from both fuels were compared. In both fuel use, the heat release is similar in the same engine load at the same crank angle. Ignition delay is longer for B30 fuel than diesel fuel at the same engine loads. Ignition delay in diesel fuel is $0.725 \mathrm{~ms}$ at $18.75 \mathrm{Nm}$ motor load and $0.875 \mathrm{~ms}$ for B30 fuel. At the same engine loads, the combustion time of the B30 fuel is longer than that of diesel fuel. As the engine load increases, the combustion times difference between diesel fuel and B30 fuel is reduced. The cyclic differences are greater in the use of B30 fuel for the same engine loads. The cyclical difference in diesel fuel at $18.75 \mathrm{Nm}$ load is $2 \%$, while in B30 fuel it is $3.25 \%$. The cumulative heat release is similar in both fuels. Obtaining the CA50 value later than TDC for the B30 fuel decreases the indicated thermal efficiency. The thermal efficiency of diesel fuel is better than B30 fuel. However, while the thermal efficiency of diesel fuel is $28 \%$ at $11.25 \mathrm{Nm}$ motor load, the thermal efficiency of B30 fuel is $26 \%$. In the same engine loads, the thermal efficiency is better rate of max $5 \%$ and min $1 \%$ in diesel fuel. The $\mathrm{CO}$ ratio is higher in diesel fuel than in biodiesel for about $31 \%$ and $12.5 \%$ at the load of $18.75 \mathrm{Nm}$ and at 3.75 $\mathrm{Nm}$, respectively. $\mathrm{CO}_{2}$ emissions of $\mathrm{B} 30$ fuel are higher than diesel fuel. The $\mathrm{CO}_{2}$ ratio of biodiesel is higher than the diesel for about $41 \%$ and $20 \%$ at the load of $11.25 \mathrm{Nm}$ and 3.75 $\mathrm{Nm}$, respectively. The $\mathrm{NO}_{\mathrm{x}}$ emission rate is higher in B30 fuel than diesel fuel at the same engine loads. $\mathrm{B} 30$ fuel has a $\mathrm{NO}_{\mathrm{x}}$ emission rate of more than $9.5 \%$ at $18.75 \mathrm{Nm}$ engine load. The rate of smoke emissions is higher in diesel fuel. Smoke emissions decreased by $37.5 \%$ in B30 fuel compared to diesel fuel at $18.75 \mathrm{Nm}$ load. As a result of the gradual decrease in petroleum-based fuels, price increases and the harmful effects on the environment, the search for a new fuel, which will be an alternative to these fuels, has become a popular subject. Biodiesel has become an important source of energy especially for the countries of agriculture because it is friendly to the environment and cheaper than that of diesel fuel. As a result, diesel biodiesel mixtures can be used in diesel engines as the nearest alternative fuel to diesel fuel even though they have lower efficiency than diesel fuel.
Abbreviations
ATDC After top dead center
BSFC Brake specific fuel consumption
CA Crank angle
CI Compression ignition
CO Carbon monoxide
$\mathrm{CO}_{2}$ Carbon dioxide
COV Cyclic of variations 
DC Direct current

NO $_{\mathbf{x}}$ Nitrogen oxides

OFR Oscillatory flow reactor

PM Particulate matter

$\mathrm{SO}_{2}$ Sulphur dioxide

$\mathrm{SO}_{3}$ Sulphur trioxide

TDC Top dead center

TDI Turbo direct injection

UHC Unburned hydrocarbon

dQ Heat release,

$\mathbf{d Q}_{\text {heat }}$ Heat transferred to cylinder walls,

d $\boldsymbol{\theta}$ Crank angle variation

$\mathbf{k} \quad$ Ratio of specific heat values

\section{Acknowledgements}

The fuel and analyzes used in this study were provided with the support of Afyon Kocatepe University Scientific Research Projects Unit number 16.FEN.BİL.05. Engine performance and emission tests were carried out at Gazi University, Faculty of Technology, Automotive Engineering Department. The authors thank to Afyon Kocatepe University and Prof. Dr. Hüseyin Serdar Yücesu gives permission to perform the tests.

\section{References}

1. Hasan M.M., Rahman, M.M., 'Performance and emission characteristics of biodiesel-diesel blend and environmental and economic impacts of biodiesel production: A review", Renewable and Sustainable Energy Reviews, 74, 938-948, (2017).

2. Abbaszaadeh, A. et al., 'Current biodiesel production technologies: A comparative review', Energy Conversion and Management, 63, 138-148, (2012).

3. Karmakar, A., Karmakar, S., Mukherjee, S., 'Properties of various plants and animals feedstocks for biodiesel production', Bioresource Technology, 101(19), 7201-7210, (2010).

4. Talebian-Kiakalaieh, A., Amin, N.A.S., Mazaheri, H., 'A review on novel processes of biodiesel production from waste cooking oil', Applied Energy, 104, 683-710, (2013).

5. Haşimoğlu, C., İçingür, Y., Özsert, İ., 'Turbo şarjlı bir dizel motorda yakıt olarak biyodizel kullanılmasının motor performans ve egzoz emisyonlarına etkisi,' Gazi Üniv. Müh. Mim. Fak. Dergisi, 23(1), 207-213, (2008).

6. Sinha, S., Agarwal, A.K., Garg, S.,
"Biodiesel development from rice bran oil: Transesterification process optimization and fuel characterization', Energy Conversion and Management, 49(5), 1248-1257, (2008).

7. Zhang, Y., Dubé, M.A., McLean, D.D., Kates, M., "Biodiesel production from waste cooking oil: 1. Process design and technological assessment', Bioresource Technology, 89(1), 1-16, (2003).

8. Pilar Dorado, M., Ballesteros, E., Mittelbach, M., Lopez, F.J., 'Kinematic Parameters Affecting the Alkali-Catalyzed Transesterfication Process of Used Oliver oil', Energy Fuels, 18(5), 1457-1467, (2004).

9. Abed, K.A., El Morsi, A.K., Sayed, M.M., El Shaib, A.A., Gad, M.S., ''Effect of waste cooking-oil Biodiesel on Performance and Exhaust Emissions of a Diesel Engine', Egyptian Journal of Petroleum, 28, 985-989, (2018).

10. Gao, Y., Chen, Y., Gu, J., Xin, Z., Sun, S., 'Butyl-biodiesel Production from Waste Cooking Oil: Kinetics, Fuel Properties and Emission Performance', Fuel, 236, 1489-1495, (2019).

11. Shen, X., Shi, J., Cao, X., Zhang, X., Zhang, W., Wu, H., 'Real-World Exhaust Emissions and Fuel Consumption for Diesel Vehicles Fueled by Waste Cooking Oil Biodiesel Blends', Atmospheric Environment, 191, 249-257, (2018).

12. Yesilyurt, M.K., "The Effects of the Fuel Injection Pressure on The Performance and Emissions Characteristics of a Diesel Engine Fuelled with Waste Cooking Oil Biodiesel-Diesel Blends", Renewable Energy, 132, 649-666, (2019).

13. Akar, M.A., Kekilli, E., Bas, O., Yıldızhan, S., Serin, H., Ozcanlı, M., 'Hydrogen Enriched Waste Oil Biodisel Usage in Compression Ignite Engine', International Journal of Hydrogen Energy, 43, 18046-18052, (2018).

14. Rajak, U., Verma, T.N., 'Effect of Emission from Ethylic Biodiesel of Edible and Non-edible Vegetable Oil, Animal Fats, Waste Oil and Alcohol ib CI engine", Energy Conversion and Management, 166, 704-718, (2018).

15. Gharehghani, A., Mirsalim, M., Hosseini, R., 'Effects of Waste Fish Oil Biodisel on Diesel Engine Combustion 
Characteristics and Emission', Renewable Energy, 101, 930-936, (2017).

16. Garcia-Martin, J.F., Barrios, C.C., AlesAlvarez, F.J., Dominguez-Saez, A., AlvarexMateos, P., 'Biodiesel Production from Waste Cooking Oil in an Oscillatory Flow Reactor: Performance as a Fule on a TDI Diesel Engine', Renewable Energy, 125, 546-556, (2018).

17. Dorado, M.P., Ballesteros, E., Arnal, J.M., Gomez, J., Lopez, F.J., ''Exhaust Emissions from a Diesel Engine Fuled with Transesterified Waste Olive oil', Fuel, 82, 1311-1315, (2003).

18. Lapuerta, M., Herreros, J.M., Lyons, L.I., Garcia-Contreras, R., Briceno, Y., ''Effect of the Alcohol Type Used in the Production of Waste Cooking Oil Biodiesel on Diesel Performance and Emission', Fuel, 87, 31613169, (2008).

19. Lapuerta, M., Rodriguez-Fernandez, J., Agudelo, J.R., 'Diesel Particulate Emissions from Used Cooking Oil Biodiesel', Biosource Technology, 99, 731-740, (2008).

20. Kalligeros, S., Zannikos, F., Stournas, S., Lois, E., Anastopoulos, G., Ch. Teas, Sakellaropoulos, F., "An Investigation of Using Biodeisel7Marine Diesel Blends on the Performance of a Stationary Diesel Engine', Biomass and Bioenergy, 224, 141-149, (2003).

21. Dorado, M.P., Ballesteros, E., Arnal, J.M., Gomez, J., Lopez Gimenez, F.J., 'Testing Waste Olive Oil Methyl Ester as a Fule in a Diesel Engine', Energy Fuels, 17(6), 1560-1565, (2003).

22. David M.D., Esra,M., Sarah H.W., Charly, K., M. Ian G., William P.L., "Mutagenicity emission factors of canola oil and waste vegetable oil biodiesel: Comparison to soy biodiesel', Mutation Research/Genetic Toxicology and Environmental Mutagenesis (in press), (2019).

23. Nawel,O., Kerras, H., Nekkab C., Merouani R., Meniai Abdesslam H., 'Biodiesel production optimization from waste cooking oil using green chemistry metrics", renewable energy (in press), (2019).

24. M.Carmona-Cabello, J.Sáez-astante, S.Pinzi, M.P.Dorado, " Optimization of solid food waste oil biodiesel by ultrasound-assisted transesterification', Fuel, 255, (2019).

25. Lombardini work shop manual.
[Online].

Available: http://service.lombardinigroup.it/documents/M anuali Officina/English/Work Shop Manual GR 6 matr 1-5302-387.pdf, 2017.

26. Heywood, J.B.,' Internal Combustion Engines Fundamentals', McGraw-Hill, USA, (1988).

27. Zhao, H.,' 'HCCI and CAI Engines for the Automotive Industry', Woodhead Publishing Limited, England, (2007).

28. Stone, R., 1999, "Introduction to Internal Combustion Engines', Macmillan Press Ltd, ISBN 0- 333-74013- 0, Tesseraux, I.; Toxicoll, Lett., 2004, 149, 295-300.

29. Uyumaz, A., Solmaz, H., Y1lmaz, E., Yamık, H., Polat, S., 'Experimental Examination of The Effects of Military Aviation Fuel JP-8 and Biodiesel Fuel Blends on the Engine Performance Exhaust Emissons and Combustion in a Direct Injection Engine', Fuel Processing Technology, 128, 158-165, (2014).

30. Uyumaz, A., 'Combustion, Performance and Emission Characteristics Of a DI Diesel Engine Fueled With Mustard Oil Biodiesel Fuel Blends At Different Engine Loads", Fuel, 212,256-267, (2018).

31. Uyaroğlu, A., Uyumaz, A., Çelikten, İ., 'Comparison of the Combustion and Emission Characteristics of Inedible Crambe Abyssinica Oil Biodiesel and Edible Hazelnut, Corn, Soybean, Sunflower and Canola Biodiesels", Environmental Progress and Sustainable Energy, 37,4, 1438-1447, (2018).

32. Can, Ö., Öztürk, E., Solmaz, H., Aksoy, F., Çınar, C., Yücesu, H.S., 'Combined effects of soybean biodiesel fuel addition and EGR application on the combustion and exhaust emissions in a diesel engine', Applied Thermal Engineering, 95, 115-124, (2016).

33. D.H. Qi, L.M. Geng, H. Chen, Y.Z.H. Bian, J. Liu, X.C.H. Ren, 'Combustion and performance evaluation of a diesel engine fueled with biodiesel produced from soybean crude oil', Renewable Energy, 34, 2706-2713, (2009).

34. O. Özener, L. Yüksek, A.T. Ergenç, M. Özkan, '"Effects of soybean biodiesel on a DI diesel engine performance, emission and combustion characteristics", Fuel, 115, 875883, (2014).

35. M. Gürü, A. Koca, Ö. Can, C. Çınar, F. 
Şahin, 'Biodiesel production from waste chicken fat based sources and evaluation with $\mathrm{Mg}$ based additive in a diesel engine", Renewable Energy, 35 (3) 637-643, (2010).

36. A.N. Özsezen, M. Canakci, "The emission analysis of an IDI diesel engine fueled with methyl ester of waste frying palm oil and its blends", Biomass Bioenergy, 34,1870-1880, (2010).

37. Sarıdemir, S., 'Biyodizel- Dizel Yakıt Karışımlarının Motor Gürültü ve Egzoz Emisyonlarma Olan Etkisi', in 4th International Symposium on Innovative Technologies in Engineering and Science, p. 187, (2016).

38. Çelik, M., 'Biyodizel Yakıt Özelliklerinin Motor Performansı ve Emisyon Karakteristiklerine Etkilerinin İncelenmesi', Doktora Tezi, Gazi Üniversitesi, Fen Bilimleri Enstitüsü, Ankara, (2015).

39. Çelik, M., Solmaz, H., Yücesu, H.S., 'Pamuk Metil Esterine N-Heptan Katkısının Motor Performansi Ve Yanma Karakteristiklerine Etkilerinin İncelenmesi', Journal of the Faculty of Engineering and Architecture of Gazi University, 30, 3, 361369, (2015).

40. İmal, M., Kaya, A., Sincar, O., ' 'Zeytinyağı Biyodizelinin Motor Performansı ve Egzoz Emisyonu Üzerindeki Etkilerinin Belirlenmesi', KSU Journal of Natural Sciences, 20(3), 283-291, (2017).

41. Çelik, M., Solmaz, H., Yücesu, H.S., 'Examination of the effects of organic based manganese fuel additive on combustion and engine performance', Fuel Processing Technology, 139, 100-107, (2015).

42. Tillem, İ., 'Dizel Motorlar İçin Alternatif Yakıt Olarak Biyodizel Üretimi ve Kullanımı', Yüksek Lisans Tezi, Pamukkale Üniversitesi, Fen Bilimleri Enstitüsü, Denizli, (2005).

43. Eliçin, A.K., 'Biyodizel Yakıtla Çalıştırılan Küçük Güçlü Bir Dizel Motorun Performans ve Emisyonuna Giriş Hava Basıncı Etkisinin Deneysel Olarak Araştırılması', Doktora Tezi, Ankara Üniversitesi, Fen Bilimleri Enstitüsü, Ankara, (2011).

44. Ilgazlı, Ö., 'Değiştirilebilir Sıkıştırma Oranına Sahip Bir Sıkıştırma Ateşlemeli Motorda Diesel-Biodiesel Karışımlarının Motor Performansina ve Emisyonlarına
Etkisinin Araştırılması', Yüksek Lisans Tezi, Yıldız Teknik Üniversitesi, Fen Bilimleri Enstitüsü, İstanbul, (2010).

45. Reşitoğlu, A.İ., "Atık Yağlardan Üretilmiş Biyodizelin Motor Performans ve Egzoz Emisyonuna Etkìsinin Deneysel Olarak Araştırılması', Yüksek Lisans Tezi, Mersin Üniversitesi, Fen Bilimleri Enstitüsü, Mersin, (2010).

46. Kaya, M., 'Bíyodizel Dizel Karışımı Kullanılan Bir Dìzel Motorda Püskürtme Basincinın Performans ve Emisyonlara Etkisi', Yüksek Lisans Tezi, Marmara Üniversitesi, Fen Bilimleri Enstitüsü, İstanbul, (2010). 